\title{
Imperfect printed enamel surfaces: interpreting marks of eighteenth- century Midland craftsmanship
}

\author{
John Grayson
}

Faculty of Arts, Design and Media, Birmingham City University, Birmingham, UK

John.Grayson@bcu.ac.uk

John Grayson is a contemporary craft maker, researcher and lecturer interested in craft-making deployed in, and objects originating from, eighteenth-century metalworking trades of the English Midlands_-Birmingham and the Black Country, principally enamel: his work contributes to both the fields of contemporary craft and material culture. In 2004/5 he received an AHRC Small Grant for Making Connections, an audience engagement project at Bilston Craft Gallery, investigating how historical enamel objects, could connect audiences, through their local industrial heritage, with contemporary craft. In 2015 he secured Arts Council England funding for Georgian Enamel: Piecing Together a New Narrative at Bantock House Museum, which interpreted and re-valued damaged and un-exhibitable enamel objects in the Wolverhampton Art Gallery collection by inclusion in new crafted objects. A STEAM Doctoral scholarship at Birmingham City University resulted in a PhD in 2019 with a thesis entitled South Staffordshire Enamels: The lost Craftsmanship of Eighteenth-Century Copper Substrate, findings were disseminated through Enamel $\mid$ Substrate, a touring exhibition for Ruthin Craft Centre. John is currently STEAM Postdoctoral Research Fellow, Faculty of Arts, Design and Media, Birmingham City University; Honorary Research Fellow, School of History and Cultures, University of Birmingham; and, lecturer at Hereford College of Arts.

https://twitter.com/jgraysondesign http://www.craftscouncil.org.uk/directory/maker/john-grayson 


\title{
Imperfect printed enamel surfaces: Interpreting marks of eighteenth- century Midland craftsmanship
}

\begin{abstract}
Eighteenth-century ceramic and enamelware manufacturers recognised that printing provided a means of applying identical decoration to three-dimensional surfaces thereby speeding up production. The process, transfer printing, used a flexible paper carrier to 'transfer' wet ink from a flat engraved copper plate to the irregular surface of an object. Whilst the ceramics industry is writ large within the grand narrative of eighteenthcentury transfer printing, the methods used by the enamelling trade are little known. Using craftsmanship-framed analysis of printed enamel boxes in Wolverhampton Art Gallery, this article will consider their printed surfaces in order to understand the technical and tacit skills developed by Midland eighteenth-century printers and decorators. Analysis of these artefacts provides, for the first time, a more comprehensive understanding of the modes of making the prints, their application, and the problems encountered.
\end{abstract}

\section{Keywords}

Birmingham; craft; enamel; eighteenth-century; manufacturing; South Staffordshire; transfer-printing. 
In May 1766 Lady Shelburne (1745-71) visited the works of John Taylor (1710/11-75)

in Birmingham, providing an eyewitness account of transfer printing being used to decorate enamelware in a Midlands Manufactory: ${ }^{1}$

The method of doing it is this: a stamping instrument managed only by one woman first impressed the picture on paper, which paper is then laid even upon a piece of white enamel and rubbed hard with a knife, or instrument like it, till it is marked upon the box. Then there is spread over it with a brush some metallic colour reduced to a fine powder which adheres to the moist part and, by putting it afterwards into an oven for a few minutes, the whole is completed by fixing the colour. ${ }^{2}$

This method of printing, invented in Birmingham around 1750, used a medium - tissue paper or gelatinous bat - to transfer an image from an engraved copper plate to the surface of a three dimensional form. ${ }^{3}$ The technique has a long-standing association with ceramics manufacture, but was also extensively used by the enamel trade. ${ }^{4}$ The method provided a means of replicating imagery and economically scale-up production through mechanised decorating.

\footnotetext{
${ }^{1}$ P. Hamilton, 'Taylor, John (1710/11-1775), button manufacturer,' (Oxford University Press, 2013) in Oxford Dictionary of National Biography

$<$ https:/www.oxforddnb.com/view/10.1093/ref:odnb/9780198614128.001.0001/odnb-9780198614128-e50560 $>$ [accessed 24 December 2019]

${ }^{2}$ E. Fitzmaurice, Life of William, Earl of Shelburne, Afterwards First Marquess of Lansdowne: 17371766 (London: Macmillan \& Co. 1875) https://play.google.com/store/books/details?id=EZ8AQAAMAAJ\&rdid=book-EZ8-AQAAMAAJ\&rdot=1 [accessed 28 July 2019], pp. 400-401.

${ }^{3}$ J. Styles, 'What was new?', in Design and The Decorative Arts: Georgian Britain, 1714-1837, ed. By M. Snodin, and J. Styles (London: V\&A Publications, 2004), pp. 147-150.

${ }^{4}$ Contemporary ceramic technical books on print provide a useful summary of the historical process and usage, see: K. Petrie, Ceramic transfer printing (London: A. \& C. Black; Westerville, Ohio: American Ceramic Society, 2011), pp. 19-32; P. Scott, Ceramics and print, 3rd edn (London: Bloomsbury, 2013), pp. 13-14. For explanation of different variants of early transfer printing on ceramics and reference to enamels and production in Liverpool, see: R. Haggar, Black-printing on porcelain, 10.1 (ECC Transactions, 1976) $<$ https://www.englishceramiccircle.org.uk/journal/index.php/ECC_Transactions/article/view/223> [accessed 4 November 2015].
} 
In the grand narrative of transfer printing, the ceramics trade is writ large, and it was used by illustrious manufacturers such as Spode and Wedgwood. On the other hand, the significance of the enamel trade in the invention, perfection and use of transfer printing is largely unacknowledged. Some scholars suggest that the process emanated from the enamel trade. This scholarship, however, paints a confused picture that initially attributes great significance to a short-lived works at Battersea, Surrey (now part of London), but gradually unpicks the significance of the Midlands in the invention of the process and its subsequent wide-spread use. ${ }^{5}$ In doing so, useful insight into the process are provided. What is missing from the secondary literature is an understanding of the craft practices of the printers and decorators in the workshop, particularly of the Midlands.

This article provides an account of how both my analysis of enamel objects - through a crafts makers lens - combined with material experiments, have not only revealed more about the processes deployed in the enamel trade, but how object replication may eventually lead to the identification of Midland manufactured enamel products. The article comprises, an introduction to enamel objects; a summary of the manufacturing process that makes apparent the importance of the Midland manufacturing ecology to the trade's emergence; a summary of existing scholarship on the variants of transfer print methods used, and geographic associations; articulation of the research methodology—object analysis and practice based material experimentation; a description of the process and data generated from the analysis of enamel objects,

\footnotetext{
${ }^{5}$ South Kensington Museum, A Guide to the Art Collections of the South Kensington Museum (London: Spottiswoode \& Company, 1870), p. 46 https://books.google.co.uk/books?id=JKifAAAAMAAJ [accessed 20 November 2012]. This guide illustrates the prevailing over significance placed on the Battersea works in the late nineteenth century, it lists the manufactories period of operation as 1750 to 1775 , and goes on to describe enamelling in Bilston as 'inferior'.
} 
material experiments; and, a conclusion that presents findings - new insights into Midland production.

\section{Midland enamels}

English Painted Enamel is the collective term used to describe a genre of enamels manufactured circa $1750-1830 .^{6}$ The trade produced decorative and useful goods for the rapidly expanding middle classes both at home and for export: objects for the home such as candlesticks, salts, tea caddies, inkstands, cutlery sets; and 'toys' for personal use including étuis, patch boxes, snuffboxes, and bonbonniers. A combination of the methods of production — a copper substrate encapsulated in enamel—with stylistic cues derived from the fashions of the day-Rococo and Neo Classical—resulted in the manufacture of objects redolent of highly fashionable porcelain. The trade occurred at various locations: York House works, Battersea (1753-56), and Sadler and Green, Liverpool (1748-99), were both significant in producing printed enamelware. ${ }^{7}$

However, the Midlands was the principal centre of production, including South

\footnotetext{
${ }^{6}$ There are few comprehensive surveys of English Painted Enamels, for usefull historical, stylistic and technical information see: T. Hughes, and G. B. Hughes, English Painted Enamels (London: Country Life; New York: Charles Scribner's Sons, 1951); and, S. Benjamin, English enamel boxes: from the eighteenth to the twentieth centuries (London: Macdonald Orbis, 1987).

${ }^{7}$ The York House manufactory was set up by London stationer Stephen Theodore Janssen with partners Henry Delamain - an Irish potter and John Brooks - an engraver. Other important associates were the notable French engraver Simon François Ravenet, and Midland engraver Robert Hancock. See: B. Rackham, Supplementary Notes on the Battersea Factory, 4 (EPC Transactions, 1932), in ECC Transactions <http:/www.englishceramiccircle.net/index.php/ECC_Transactions/article/view/5> [accessed 4 November 2015] pp. 69-74; B. Rackham, Porcelain as a Sidelight on Battersea Enamels, 4 (EPC Transactions, 1932), in ECC Transactions

$<$ http://www.englishceramiccircle.net/index.php/ECC_Transactions/article/view/5> [accessed 4 November 2015] pp. 45-57; and, H. Read, Cross-Current in English Porcelain, Glass, and Enamels, 4 (EPC Transactions, 1932), in EEC Transactions $<$ http://www.englishceramiccircle.net/index.php/ECC_Transactions/article/view/5 [accessed 4 November 2015] pp. 7-16. Sadler and Green, set up by John Sadler, claimed credit for the invention of transfer printing in 1749, however it appears his knowledge was derived from the closed Battersea works. They produced printed ceramic and enamelware - predominantly medallions, see: S. Benjamin, English enamel boxes: from the eighteenth to the twentieth centuries (London: Macdonald Orbis, 1987), pp. 88-93.
} 
Staffordshire — Bilston and Wednesbury — and Birmingham. ${ }^{8}$ Production relied on craft skills juxtaposed with early forms of industrial manufacturing comprising the division of labour, outsourcing, and the use of simple forms of mass-production — the stamping of metal components and the embryonic transfer printing process. Current understanding of the methods employed by the trade in general is limited due to a dearth of primary documentation providing technical description or witness accounts of making.

Trade directories of the time and witness accounts by the industrial tourist Reinhold Angerstein (1718-60) allude to the multiplicity of small workshops engaged in the Midlands enamel trade. ${ }^{9}$ However, because they did not mark their ware there has been much confusion over attributing enamel artefacts to their sites of manufacture-either their geographic locations or specific workshops.

After the demise of the trade at the end of the nineteenth century, enamels became popular items for collectors who believed that the majority of the stylistically more sophisticated ware was a product of Battersea, whilst the Midland manufactories produced the less refined products. During the late-nineteenth and early-twentieth centuries, as a number of significant collections passed to museums, this belief

\footnotetext{
${ }^{8}$ For information on individuals and families engaged in the enamel trade in Bilston, see: E. Benton, The Bilston enamellers, 7.3 (ECC Transactions, 1970)

$<$ http://englishceramiccircle.net/index.php/ECC_Transactions/article/view/647> [accessed 4 November 2015]; T. Cope, Bilston Enamels of the 18th Century (Tipton, West Midlands: Black Country Society, 1980).

${ }^{9}$ For references to enamelling and enamellers in Bilston and Wednesbury, see : R. R. Angerstein, R.R. Angerstein's illustrated travel diary, 1753-1755: industry in England and Wales from a Swedish perspective, trans. by Torsten and Peter Berg (London: Science Museum), pp. 42-43, 47-48, 52, 345; The Birmingham, Wolverhampton, Walsall, Dudley, Bilston, and Willenhall Directory; or, merchant and tradesman's useful companion [...] (Birmingham: Pearson and Rollason: 1780), in Eighteenth Century Collections Online

http://find.galegroup.com/ecco/infomark.do?\&source=gale\&docLevel=FASCIMILE\&prodId=ECCO\&us erGroupName $=$ uce $\&$ tabID $=$ T001\&docId $=$ CW3306033475\&type $=$ multipage $\&$ contentSet $=$ ECCOArticles \&version=1.0 [accessed 12 May 2017].
} 
continued. However, a paradigm shift in thinking occurred as a consequence of the Schreiber collection of enamels which was donated to the South Kensington Museum in 1884. ${ }^{10}$ Bernard Rackham, Keeper of Ceramics at the Museum, undertook an extensive analysis of the collection, making comparison with the chronology of the emergence of styles, colour invention and provenance. His findings, published in The Catalogue of the Schreiber Collection concluded that much of the ware was produced by the numerous Midland manufactories. ${ }^{11}$ This, perhaps, was not surprising given the diverse manufacturing ecology that was emerging in the region in the mid-eighteenth century and which provided the right mix of material sources, technical and tacit making skills, craft knowledge and technical innovation. However, despite the corpus of research undertaken since Rackham's catalogue, linking enamelware to specific Midland factories has, to date, been near impossible. ${ }^{12}$

\section{Enamel objects: Midlands materials, craftsmanship and construction}

To make enamel objects economically required a multitude of skills unlikely to be possessed by one individual. Outsourcing, or divided labour, provided the means to scale-up production. For the larger works this may have been undertake in-house, for the smaller concerns outsourcing would likely have occurred.

\footnotetext{
${ }^{10}$ Charles Schreiber Esq. M.P. (1826-1884) and The Lady Charlotte Elizabeth Schreiber (1812-1895) collected porcelain, glass and enamel, see: Angela V. John, 'Schreiber [née Bertie; other married name Guest], Lady Charlotte Elizabeth (1812-1895), translator, businesswoman, and collector,' (Oxford University Press, 2004) in Oxford Dictionary of National Biography $<$ https://www.oxforddnb.com/view/10.1093/ref:odnb/9780198614128.001.0001/odnb-9780198614128-e24832> [accessed, 24 December 2019].

${ }^{11}$ B. Rackham, Catalogue of English Porcelain, Earthenware, Enamels and Glass collected by Charles Schreiber and the Lady Charlotte Elizabeth Schreiber [...] (London: Authority of the Board of Education, 1924), pp. 3-13.

${ }^{12}$ EM217 is significant because it depicts Sam Proud's asylum $1770-1781$. His nephew Isaac Beckett was one of the principle enamellers in Bilston, this enamel is attributed to his manufactory, and, consequently ones of similar design to Bilston. See: Wolverhampton Arts and Culture, 'Patch Box EM217'<http://www.wolverhamptonart.org.uk/collections/getrecord/WAGMU_EM217> [accessed 19 December 2019].
} 
The construction of the objects brought together the craft skills and technical knowledge of the area. Copper was needed in order to be rolled into thin foil and was probably sourced from Ecton Hill copper mine in North Staffordshire; Angerstein witnessed metal rolling on his travels between Birmingham and Bilston. ${ }^{13}$ The box maker's skill was needed to create the form to be enamelled. Mineral resources were required for firing and large deposits of coal could be found in South Staffordshire and refractory clay was available in nearby Stourbridge to make the all important muffles and coffins in which to fire the enamelware. ${ }^{14}$ Finally, the skills required to engrave copper plates for the creation of the prints could be found in the local metalworking trades. The synthesis of pre-existing material resources with the craft skills and the ingenuity of the individuals within the toy trade, driven by emerging consumer demands, probably played a major role in the emergence of Midlands enamel manufacturing in the period.

An explanation of enamel manufacture crystallises understanding of the complex, multifaceted process, and highlights the implications for production - the importance of having materials and resources available locally and to hand. ${ }^{15}$ Firstly, copper foil with a gauge of $0.010 \mathrm{inch}$ - the thickness of a piece of cartridge paper-was transformed by the copper-box maker from sheet to form. Secondly, the flimsy sheet was stamped or hand manipulated into components and then crimped or tied together. This stage of

\footnotetext{
${ }^{13}$ S. Benjamin, English enamel boxes: from the eighteenth to the twentieth centuries (London: Macdonald Orbis, 1987), p. 30; R. R. Angerstein, R.R. Angerstein's illustrated travel diary, 1753-1755: industry in England and Wales from a Swedish perspective, trans. by Torsten and Peter Berg (London: Science Museum), p. 39.

${ }^{14} \mathrm{~A}$ muffle - a refractory clay tube, a coffin - a lidded clay box like a saggar used in the ceramic trade, protected the ware from the furnace fire. Muffles were best for firing single objects and coffins for batches. For a comprehensive explanation of furnace, muffle and coffin construction and their attributes see: R. Dossie, The Handmaid to the Arts (London, 1758)

$<$ https://archive.org/details/handmaidtoartsb00dossgoog > [accessed 19 October 2016], pp. 233-243.

${ }^{15}$ Until recently a significant knowledge gap existed in enamel literature on the methods used to construct the copper forms to be enamelled, J. Grayson, 'South Staffordshire Enamels: The lost craftsmanship of eighteenth-century copper substrate' (PhD diss., Birmingham City University, 2019), provides a survey and, technical and pictorial description of the methods.
} 
production may have been outsourced but while the processes generated rigidity the copper form — the substrate — was still vulnerable to deformation when being transported. Thirdly, the ground coats of enamel and decorative topcoats were applied to the metal substrate and fired. Each stage of the enamel application required different knowledge-sets. The copper substrate was easily misformed through the stress caused by the enamel as it vitrified during firing at around $800^{\circ} \mathrm{c}$ and contracted during cooling. Variation in the thickness of enamel ground could exert tension differentials and multiple firings compounded risks of warping. The application of enamel grounds by dipping, although appearing simple, required uniformity. The skill of individuals who worked the kilns was crucial in ensuring the enamel was neither under- nor over-fired and that smooth enamel surfaces were created in order to take decoration. Finally, once the components had been enamelled they had to be transformed into functional ware by a mount turner. Boxes had to be joined to their lids with a hinged mount, candlesticks required edging, larger sticks being constructed from multiple stems joined by base metal mounts to over come the size limitations of what it was possible to fire. It was only in the Midlands - Birmingham and the surrounding districts — where a diverse manufacturing ecology was emerging, that all the necessary materials, trades and skills could be found. ${ }^{16}$

Rackham's publication acted as a catalyst for scholars to undertake further research into English Painted Enamels, principally investigating the individuals involved in the trade, their decoration, styles and methods of manufacture of which transfer printing became a significant focus. Papers presented to the English Ceramic Circle (ECC), such as

\footnotetext{
${ }^{16}$ M. Dick, 'The City of a Thousand Trades, 1700-1945,' in Birmingham the Workshop of the World, ed. by Carl Chinn and Malcolm Dick (Liverpool: Liverpool University Press, 2016), pp. 127-137, provides a summary of the diversity of trades in and around Birmingham and the reasons behind emergence and growth.
} 
Toppin's Notes on Janssen and Hughes's Authorship of some designs on porcelain and enamel, critically analysed the York House works and the role of celebrity engravers such as Simon François Ravenet (1721-74) and Robert Hancock (bap.1731-1817). ${ }^{17}$ On the other hand, Watney and Charleston's four-part Petitions for patents concerning porcelain, glass and enamels: Birmingham The great toyshop of Europe considered evidence of transfer printing in Birmingham and South Staffordshire, linking John Brooks (c.1710-after 1756), a Dublin born engraver who unsuccessfully lodged a patent for transfer printing in 1751 whilst in Birmingham, and Hancock to enamel printing in the region before the demise of the Battersea works, further disrupting established thought on the origins of enamel printing. ${ }^{18}$ To a greater extent these authors focused on the emergence of transfer printing across the trade. Whilst some descriptions of the process are provided, such as Lady Shelburne's account, their focus was on establishing

\footnotetext{
${ }^{17}$ A. J. Toppin, Notes on Janssen, and the artists at the Battersea Factory, 4 (EPC Transactions, 1932), in EEC Transactions <http://www.englishceramiccircle.net/index.php/ECC_Transactions/article/view/5> [accessed: 4 November 2015), pp. 58-68; H. W. Hughes, (1935) Authorship of some designs on porcelain and enamel and Robert Hancock's connection with Battersea and Bow, 1.3 (EPC Transactions, 1935) in ECC Transactions <http://englishceramiccircle.net/index.php/ECC_Transactions/article/view/27> [accessed 4 November 2015]. For biographies of Ravenet and Hancock see: Sheila. O'Connell, 'Ravenet, Simon François (1721-1774), engraver,' (Oxford University Press, 2004) in Oxford Dictionary of National Biography

$<$ https://www.oxforddnb.com/view/10.1093/ref:odnb/9780198614128.001.0001/odnb-9780198614128-e$23170>$ [accessed, 24 December 2019]; and, Anne. Puetz, 'Hancock, Robert (bap. 1731, d. 1817), engraver,' (Oxford University Press, 2004) in Oxford Dictionary of National Biography $<$ https://www.oxforddnb.com/view/10.1093/ref:odnb/9780198614128.001.0001/odnb-9780198614128-e12186> [accessed, 24 December 2019]

${ }^{18} \mathrm{~B}$. Watney, Petitions for patents concerning porcelain, glass and enamels Birmingham The great toyshop of Europe Part 1a, 6.2 (ECC Transactions, 1966)

$<$ http://www.englishceramiccircle.net/index.php/ECC_Transactions/article/view/171> [accessed 4 November 2015]; B. Watney, Petitions for patents concerning porcelain, glass and enamels Birmingham The great toyshop of Europe Part 2a, 6.2 (ECC Transactions, 1966)

$<$ http://www.englishceramiccircle.net/index.php/ECC_Transactions/article/view/173> [accessed 4th November 2015]; R. J. Charleston, Petitions for patents concerning porcelain, glass and enamels Birmingham The great toyshop of Europe Part 1b, 6.2 (ECC Transactions, 1966)

$<$ http://www.englishceramiccircle.net/index.php/ECC_Transactions/article/view/172> [accessed 4 November 2015); R. J. Charleston, Petitions for patents concerning porcelain, glass and enamels Birmingham The great toyshop of Europe Part 2b, 6.2 (ECC Transactions, 1966)

$<$ http://www.englishceramiccircle.net/index.php/ECC_Transactions/article/view/174> [accessed 4 November 2015]. For a biography of John Brooks see: Anne. Puetz, 'Brooks, John (b. c. 1710, d. after 1756), engraver and print publisher,' (Oxford University Press, 2004) in Oxford Dictionary of National Biography < https://www.oxforddnb.com/view/10.1093/ref:odnb/9780198614128.001.0001/odnb9780198614128-e-3566> [accessed, 24 December 2019]
} 
the occurrence of printing rather than in-depth investigations of the printing processes used or workshop practices.

Later papers by Colin Wyman and David Drakard are more relevant to understanding the transfer printing processes. Wyman's The early techniques of transfer-printing revealed written accounts of the eighteenth century — Lady Shelburne's reappearswhile technical writing and patent applications emanating from Liverpool, particularly those of John Sadler, provide useful insight into the paper transfer process. ${ }^{19}$ Wyman also provides accounts of the different techniques of image transfer from engraved copper plate to an enamel or porcelain surface using either a 'bat' made from 'gelatinous animal glue' or paper. Drakard's article A report on the seminar on early on-glaze transfer printing brings these written accounts alive. ${ }^{20}$ His article is based on a practical recreation of the two processes by Paul Holdway, engraver and printer at the Spode Works Museum. ${ }^{21}$ Holdway’s experiments developed craftsmanship understanding of the processes and their material characteristic. Key to this research is his description of specific witness marks - the marks created by specific making methods that are interpretable and indicative of a given method of manufacture - that reveal the process. Holdway's experiments suggest the bat print provided greater clarity of print definition because the flexibility of the transfer membrane allowed prints to conform to irregular porcelain and enamel surfaces without image loss. However, he noted that the impervious membrane created blister and bubble marks in the print,

\footnotetext{
${ }^{19} \mathrm{C}$. Wyman, The early techniques of transfer-printing, 10.4 (ECC Transactions, 1979) $<$ https://www.englishceramiccircle.org.uk/journal/index.php/ECC_Transactions/article/view/239> [accessed 18 November 2015], pp. 191-192, 189-195.

${ }^{20}$ D. Drakard, A report on the seminar on early on-glaze transfer printing, 15.3 (ECC Transactions, 1995)<https://www.englishceramiccircle.org.uk/journal/index.php/ECC_Transactions/article/view/416> [accessed 18 November 2015], pp. 331-340.

21 'ibid', p. 332.
} 
caused by trapped air. ${ }^{22}$ The paper printing experiments revealed that because of the paper's inability to stretch, prints had to be segmented in order to conform to highly irregular surfaces and that the printed paper could crease during application, creating linear gaps in the printed image..$^{23}$ Therefore he considered the tissue print was characterised by lower definition.

Bernard Watney looked at evidence of bat printing and made a correlation with enamelware already attributed to Battersea. ${ }^{24}$ Wyman in $A$ review of early transfer printing techniques, summarised descriptions of transfer printing in primary and secondary literature. In his paper he translates the earliest known account of the transfer process found in the writings of Frenchman Jean Hellot (in 1759) and originating from Jacques Louis Brolliet, and therefore thought to be that used at Chelsea and possibly Battersea. ${ }^{25}$ Because Brolliet may have worked in the Chelsea works and was an acquaintance of Ravenet the suggestion is that this points to paper as the preferred transfer method. Wyman presents Brolliet's technical description:

...to print on porcelain or on a slab of enamelled copper the opposite impression of any print: first clean the engraved copper plate then run a little of the mordant...across the top and force it (into the grooves) with a roll of flannel bound up extremely tightly with fine string: then wipe it with the palm of the hand. When all the surface of the copper plate is not greasy, apply as a printer

\footnotetext{
22 'ibid', p. 336.

23 'ibid', pp. 333-334.

24 'ibid', p. 337.

${ }^{25}$ C. Wyman, A review of early transfer printing techniques, 16.3 (ECC Transactions, 1998) < https://www.englishceramiccircle.org.uk/journal/index.php/ECC_Transactions/article/view/460> [accessed 18 November 2015]. He provides explanation of the importance of Brolliet's description in relation to transfer printing in English primary and secondary literature. Brolliet's print knowledge is important because of its transferal to Sèvres Porcelain manufactory. For Hellot's original French manuscript and more information on its discovery in a French archive, see: B. Dragesco, English Ceramics in French Archives (London, 1993), in The French Porcelain Society, Monographs < https://www.thefrenchporcelainsociety.com/wp-content/uploads/2017/05/English-Ceramics-in-FrenchArchives-\%E2\%80\%93-1993.pdf $>$ [accessed, 24 December 2019].
} 
would do for a light engraving a paper moistened in the morning and having heated the copper plate pass it two times between rollers where the face of the cylinder are covered by flannel, then the design is printed in a reddish pink colour: which is the colour of the mordant. Leave the paper to dry if it is still damp: but not so much as to let the mordant itself dry: because that must remain sticky: Otherwise the lines of this reddish pink print would not hold the colour one would want them to hold $[\ldots]^{26}$

He then explains how finely crushed enamel is dusted over the sticky mordant using a piece of cotton.

Then place the print, the coloured side down on to the porcelain. Place on top another white paper and with an ivory polisher rub lightly but firmly on the second paper making sure not to move the print or to leave any spot unrubbed with the ivory polisher. After a quarter of an hour lift the print and (so) find the porcelain printed in the colour. Leave it to dry, taking great care that nothing touches it because one would remove the colour and the print would be spoiled. Then fire it either in the muffle kiln or in the painting (enamel) kiln. ${ }^{27}$

Finally one other source is worth highlighting. Hackwood in Wednesbury Workshops provides an account of the enamel process used in Wednesbury, which was acquired through interviewing Nathaniel Hadley (d.1895), one of the last craftsmen involved in the enamel trade, who was employed by Wednesbury enameller John Yardley (1770-

\footnotetext{
${ }^{26}$ C. Wyman, A review of early transfer printing techniques, 16.3 (ECC Transactions, 1998) < https://www.englishceramiccircle.org.uk/journal/index.php/ECC_Transactions/article/view/460> [accessed 18 November 2015], p. 312. 27 'ibid'.
} 
1854) ${ }^{28}$ Hackwood's description has similarities with Broilliet's but differs in that he suggests that gummed paper was used. Once printed this was left to dry, removed from the copper plate by warming and then applied to the enamelled surface by re-moistening and using the gum to adhere it to the enamel. It was then fired and the paper burned away leaving the pigment fast in the enamel. For a contemporary enameller, the burning away of the paper appears incongruous as ash would form a contaminant that could leave marks on the enamel surface: this raises questions over the accuracy of this description.

The descriptions of the process could be seen as contradictory. However, these conflicting narratives may also be interpreted as showing an evolving technologydifferent manufacturers experimenting with perfecting the process, each developing variants to make it work.

Whether written from the knowledgeable perspectives of the inventor or the non-expert jottings of the industrial tourist, this material provides useful insight into the technical aspects of enamel printing. What is missing from the written descriptions is an account of the tacit skills used and the localised struggles with the processes required to ensure the success in decorating the ware. Eighteenth-century descriptions tell us little about the craftsmanship deployed daily in the workshops: for example, the reasons why paper was dampened, or why clean paper was used to cover the printed-paper whilst burnishing. In the absence of written documentation the enamel artefacts and the

\footnotetext{
${ }^{28}$ Primary literature relating to the Wednesbury trade is limited: Hackwood, a nineteenth-century historian whose writing is treated with caution due to lack of verifiability, provides an account of the enamelling processes of which the use of liquid enamel was corroborated by Angerstein's diary, see: F. W. Hackwood Wednesbury Workshops; or, some account of the industries of a Black Country town [...] (Wednesbury: The Woden Press, 1889) pp. 13-19. For further information on Wednesbury enamellers see: T. Hughes, and G. B. Hughes, English Painted Enamels (London: Country Life; New York: Charles Scribner's Sons, 1951) pp. 104-107; T. Cope, Bilston Enamels of the 18th Century (Tipton, West Midlands: Black Country Society, 1980) pp. 128-133.
} 
witness marks found on them provide important clues to this vital but absent knowledge.

\section{Investigating printed surfaces}

My research on printed enamel boxes was undertaken using an object analysis method with its roots in Jules Prown's Mind in Matter and adapted in the light of Tara Hamling's article Visual and Material Sources. ${ }^{30}$ Importantly to this research, the latter advocates the value of interdisciplinary approaches. My enquiry is shaped by an understanding of technical and tacit knowledge which has been derived from my formal craft training and empirical workshop knowledge. ${ }^{31}$

The value of objects as sites of embodied knowledge about making are significant. Knowledge based on literature alone only allows a partial understanding of artisanal practices of the past. Consequently, workshop material experimentation and replication are gaining traction. Pamela H. Smith's introduction to Ways of Making and Knowing and the ARTECHNE project demonstrates the importance of hands-on making in historical research. ${ }^{33}$

\footnotetext{
${ }^{30}$ J. D. Prown, Mind in Matter: An Introduction to Material Culture Theory and Method, 17.1, (University of Chicago Press: Winterthur Portfolio, 1982), http://www.jstor.org/stable/1180761 [accessed, 9 July 2010]; T. Hamling, 'Visual and Material Sources,' in Understanding Early Modern Primary Sources, ed. by L. Sangha, and J. Willis (Abingdon: Routledge, 2016) pp. 129-152. In addition, L, Hannan and S. Longair, History Through Material Culture (Manchester: Manchester University Press, 2017), provides a comprehensive guide to object-based research methods for historians.

${ }^{31}$ The author is a contemporary craft maker who creates art-based narrative objects in enamelled metal. See: Crafts Council, 'Directory, John Grayson,' in $<$ https://www.craftscouncil.org.uk/directory/maker/john-grayson> [accessed December 23, 2019] ${ }^{33}$ H. J. Cook, P. H. Smith and A. R. W. Meyers, 'Introduction: Making and Knowing,' in Ways of Making and Knowing: The Material Culture of Empirical Knowledge, ed. P. H. Smith, A. R. W. Meyers and H. J. Cook (New York City: Bard Graduate Centre, 2017), p.8. Utrecht University and University of Amsterdam, 'ARTECHNE - Technique in the Arts, 1500-1950,' https://artechne.wp.hum.uu.nl [accessed December 23, 2019]
} 
The existing scholarship provides written technical descriptions of transfer printing in the enamel trade, but tells us little of the tacit skills used in daily print production. The contemporary craftsman, when reading these accounts, is aware of absent processes. In November 2015, I visited Burleigh Pottery’s Middleport works, Stoke-on-Trent, to witness tissue printing. The company has used the process continuously since its inception in 1851 and is the last manufacturer to use this decorating method. The factory visit revealed how tissue paper, freshly printed with monochrome decorations, was cut and applied to the ceramic ware registering motifs on irregular and inaccessible ceramic surfaces with great skill and speed. It illuminated the division of labour-how different operatives were engaged in printing, applying, and releasing the tissue from the ceramic surface. The tacit craft skills these individuals possessed and intuitively utilised enabled them to make the process look easy. However, it could not be fully understood either through observation or discussion with the workers.

Burleigh provided me with a small sample of the printed tissue for experimentation. The pieces, stored in an airtight plastic box to prevent drying-out, were transported back to Wolverhampton. Here I experimented with applying the paper to enamel plaques, emulating the processes I had witnessed. What became apparent was the performance of the media — tissue and ink - and the process of image transferral. Particularly, how burnishing adhered the ink to the enamel; how the oily ink and water repelled allowing the tissue to be soaked off to leave the image on the enamel; and, critically how, once the ink began to dry on the tissue, it inhibited the adherence to the enamel surface, resulting in the production of a faint image. This highlighted how eighteenth-century technical writing provided little insight into the tacit knowledge of the craftsmen on the shop floor. It also enabled the development of craft making knowledge that in 
combination with the insights of past scholars, could be used to analyse enamel artefacts in the Wolverhampton Art Gallery collection.

Wolverhampton Art Gallery holds the most significant collection of English Painted Enamels outside the Victoria and Albert Museum. ${ }^{34}$ Its printed enamel objects fall into three categories:

- Complete objects with monochrome printed decoration such as snuff and patch boxes, étui, pounce pots;

- Complete objects (as previously described), but where the printed image acted as an outline for over-painting to speed up production;

- Monochrome printed 'plaques' - slightly convex printed enamels, which were either designed to be a medallion for display or were components that had become separated from their companion object, for example, a lid from a box.

Only monochrome printed boxes in the collection were considered because they provided a clear printed surface for identification. Only objects exhibiting print irregularities were examined, the rationale being that these faults could potentially provide insight into the craftsmanship of production. Four objects were selected for indepth analysis in the gallery stores.

- EM23, a large snuffbox attributed to Battersea;

- EM47, a large rectangular snuffbox attributed to Birmingham;

\footnotetext{
${ }^{34}$ The Wolverhampton collection is digitally accessible, see: Wolverhampton Arts and Culture, 'Collections,' < http://www.wolverhamptonart.org.uk/collections/> [accessed December 23, 2019]. Currently, the Victoria and Albert Museum collection is not digitized.
} 
- EM48 a large oval snuffbox, that utilised the same prints as EM47 and is also attributed to Birmingham;

- BA358, a small oval snuffbox attributed to Bilston.

Data was recorded through written records on an object analysis form, photography, microscopy and drawing. Analysing the misprints in the context of craftsmanship helped interpretation of the possible cause of marks and what they reveal about production skills and process. Finally, analysis shifted to process replication in the contemporary craft workshop: through making, a tacit understanding was developed, and, importantly, knowledge not explicit in the written account of the process was identified.

The inclusion of Battersea box EM23 (fig. 1 \& 2) may appear incongruous in research about Midlands transfer printed enamel. However, it is important to understand that production at the Battersea works was supported by the knowledge and expertise of two Midlands printers, John Brooks and Robert Hancock. On 10 September 1751 while living in Birmingham, Brooks lodged the first of three failed petitions for patents concerning transfer printing which evidences the process was developed in the Midlands. ${ }^{35}$ Hancock was apprenticed to the Birmingham engraver George Anderton in 1746 and was connected to Battersea. ${ }^{36}$ After its bankruptcy Hancock worked as an engraver at Worcester Porcelain from circa 1756, and was director from 3 March 1772 until October 1774, after which, for a short period, he became connected to Midlands ceramic manufacturer Caughley circa 1775, and subsequently engaged in engraving for

\footnotetext{
${ }^{35}$ B. Watney, Petitions for patents concerning porcelain, glass and enamels Birmingham The great toyshop of Europe Part 1a, 6.2 (ECC Transactions, 1966)

$<$ http://www.englishceramiccircle.net/index.php/ECC_Transactions/article/view/171> [accessed 4 November 2015], pp. 60-62.

${ }^{36}$ British Book Trade Index, ‘Anderton, George,' http://bbti.bodleian.ox.ac.uk/details/?traderid=1252 [accessed December 24, 2019]
} 
publishing, particularly portraiture. ${ }^{37}$ A number of prints thought to be the work of Hancock appear on Midlands-attributed enamels; however, it is unclear if these were a product of his activity during or after his time at Worcester. ${ }^{38}$ Consequently, Midlands transfer printing was bound up with that used at Battersea.

The Battersea box EM23 is square with baluster shaped sides. The six prints on the external surfaces are all attributed to Ravenet, who depicted 'Laocoön and the Horse of Troy' on the lid. The four prints on the box sides are the most intriguing, featuring prints of Ravenet's children representing 'painting', 'sculpture', 'astronomy' and 'commerce'. Close inspection using an Optivisor magnifying glasses, microscopy and photography revealed two distinct errors in the printing. The first (fig. 1) was a gap line in the print of 'commerce' through the rococo scroll. This appeared to be evidence of paper as the transfer medium of the sort identified by Holdway, the gap being produced by a crease in the paper that prevented the tacky mordant/printing-black — eighteenthcentury terms for enamel 'ink' — coming into contact with the enamel. This appears to confirm Wyman's proposition that the Battersea works used paper rather than bat. Two of the prints, 'commerce' and 'painting', had a repetition of printed lines in the top half (figs. 2), whilst the image at the bottom was crisp. This seemed odd: were these lines engraved? The same print appears on EM 24 which was completely crisp throughout and therefore confirmed the marks did not originate from the engraved copper plate. This raised the question, what was the cause of these lines and what could this tell us? The repetition of the lines appeared to be misregistration of the print. This phenomenon is known to print makers and is produced when an inked printing plate briefly touches

\footnotetext{
${ }^{37}$ C. Cook, The Life and Work of Robert Hancock (London: Chapman \& Hall, 1948), pp. 5, 7, 9-10.

38 'ibid', pp. 9, 66-69.
} 
the surface to receive the print and is subsequently moved slightly before the full pressure is applied creating a repetition of line.

Brolliet stipulated that the paper must not move during rubbing but he did not explain the consequences. The misprint on EM23 is probably the product of this act. Beyond poor craftsmanship this detail provides evidence of the sequence in which transfers were applied by the decorators. Let us consider why the image is sharp at the base but misregistered at the top. Material experiments with tissue prints showed that paper sticks where it is first burnished; however the paper can deform during the process and shift where it is not fixed to the enamel surface. This suggests that the print would have been first placed at the base of the box and burnished from the bottom up. Because of the curve, the paper shifted in the top half, where the box transitions from convex to concave, and repositioned itself resulting in the repetition of line.

Early scholarship assumed that the more refined printed objects originated from Battersea through the association with skilled engravers such as Ravenet and Brooks, and that ware decorated with unsophisticated prints was a product of Midland's manufactories. Furthermore it was considered that where enamels with high quality prints could be attributed to the Midlands, they were produced after the bankruptcy of the Battersea manufactory—-knowledge and materials transferring to the Midlands. However, the evidence that printing occurred before and concurrent to the Battersea operation, combined with some of these individuals being connected to the Midlands before, as well as after the Battersea demise, means that the quality of the printed ware produced in the Midlands should be considered as varied in quality-from the sophisticated to less refined prints_-variation being dependent on the skill and 
knowledge of the particular workshop and the type of ware being decorated and its intended customer.

Two table snuffboxes-EM47, an oblong container measuring $73 \mathrm{~mm} \times 92 \mathrm{~mm}$, and, EM48 (fig. 3 \& 4) an oval box of similar dimensions - both attributed to Birmingham manufacturers feature the same side prints of Britannia and the Prince of Wales. ${ }^{39}$ Comparative analysis of these illuminates the problematic nature of the materials and processes faced by the Midlands decorators, even when working from the same copper plate. ${ }^{40}$ Close inspection revealed the design and the engraving marks to be identical. Each print contained imperfections that did not originate from the incised copper plate. Analysis of the side print on EM48 reveals distinct horizontal parallel lines, yet the same markings are not visible on box EM47 (fig. 3). This raises the question why? The markings are unlikely to have originated from the printing plate, but could be attributed to variables in production either in the preparation of the transfer or its method of application to the enamel surface. So what could be the cause? These witness marks when considered in relation to Brolliet's technical description could provide clues. Firstly, Brolliet's account revealed that the paper required 'rubbing with an ivory polisher'. Could the cause be a residue of lines in the print where uneven pressure has been applied? This seems unlikely given the straightness and uniformity of the parallel

\footnotetext{
${ }^{39}$ See: Wolverhampton Arts and Culture, 'Enamelled Box'

$<$ http://www.wolverhamptonart.org.uk/collections/getrecord/WAGMU_EM47> [accessed 19 December 2019]; Wolverhampton Arts and Culture, 'Enamelled Box'

$<$ http://www.wolverhamptonart.org.uk/collections/getrecord/WAGMU_EM48> [accessed 19 December

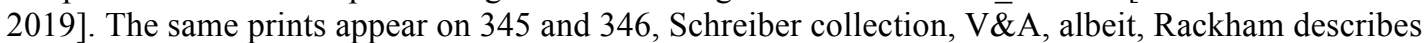
them as featuring Britannia and a man with a plumed hat, and attributes to either Bilston or Wednesbury, see: B. Rackham, Catalogue of English Porcelain, Earthenware, Enamels and Glass collected by Charles Schreiber and the Lady Charlotte Elizabeth Schreiber [...] (London: Authority of the Board of Eduction, 1924), pp. 64-65, pl. 37.

${ }^{40}$ The occurrence of these prints on EM50, a George III coronation box, suggests a box manufacture date of 1761 in this instance, see: Wolverhampton Arts and Culture, 'Enamelled Box' $<$ http://www.wolverhamptonart.org.uk/collections/getrecord/WAGMU_EM50> [accessed 19 December 2019].
} 
marks because hand-movements have an arcing gesture which would produce a curved, irregular line. Drakard initially questioned if paper would have been a viable means of image transfer in the early trade because of its roughness; however, he provides evidence of its use. Perhaps these lines were caused by a paper texture? However another material could have been the cause. Different accounts of the printing process describe how flannel was placed between the paper and the printing rollers in order to force the paper into the ink-filled engravings and pull out the 'mordant'. This raises the question, were the lines the result of a weave texture within the fabric? It is not possible to know for certain but the differences in print quality illuminate the problematic variables with which the decorators had to work.

Finally, the EM47 Britannia print has a strange gradation of opacity (fig. 4). Could the printed decoration have worn off through use? This has been seen at touch points at the bases of some enamel items such as tea caddies. In this instance this was discounted, because if this were a result of post-manufacturing abrasion the image would have been protected at the top edge by the mount adjacent to it and so appear bold at the top under the rim and worn at the bottom. This points to the fade being a product of the processpossibly a mistake during the making of the transfer or its application to enamel. Brolliet states that the mordant must remain sticky on the paper. Whilst he does not state explicitly why, the inference drawn is that otherwise the image cannot be transferred on to the enamel surface. Experiments with tissue-print supplied by the Burleigh Pottery revealed that the printed media had to be used whilst tacky otherwise the print could not be transferred. This revealed a shelf life to the print, and a correlation between the dryness of the ink and the opacity of the print. It is therefore most likely this imperfection is a consequence of the ink drying out on the tissue. This raises 
questions over the time frame between printing the image on to the transfer paper and application; whether batches could be printed and stored; and the proximity of the print shop to the location in which the boxes were decorated-an area of debate amongst scholars of early transfer-printed ceramics ${ }^{41}$.

BA358, a small oval patch box, thought to have been manufactured in Bilston circa 1760-80, typifies the 'toys' — snuff or patch boxes — associated with the town. Patchboxes were differentiated from snuffboxes by the inclusion of a mirror in the lid to aid application of the small black silk patches - beauty spots. ${ }^{42}$ Patch-boxes were oval, round, or square in shape, and decorated with bold, simple prints commemorating events, popular destinations, famous people, love mottos, or pastoral scenes. BA358 has a printed lid depicting a river scene surrounded by a patterned border. The box is coated with an undecorated pink enamel ground. An analysis of the print revealed incomplete image transfer at the edges. Object analysis concluded that this was the result of the paper lifting away from the convex outer surface of the enamel during application. In addition, the surface contains a number of small fissures — brown dots - products of contamination, either in the copper surface before enamelling, in the enamel when applied to the copper, or present during firing of the enamel. Box BA358 was chosen for replication because the print was simply engraved. As I engraved the replica printing plate the level of skill required to cut the fine detail became apparent: it was difficult to see the design drawn on the plate, problematic to position cuts accurately, and difficult to control the tool—one slip produced an irreparable cut in the wrong place. Black

\footnotetext{
41 C. Wyman, A review of early transfer printing techniques, 16.3 (ECC Transactions, 1998) < https://www.englishceramiccircle.org.uk/journal/index.php/ECC_Transactions/article/view/460> [accessed 18 November 2015] p. 307.

${ }^{42}$ Wolverhampton Arts and Culture, 'Patch box'

$<$ http://www.wolverhamptonart.org.uk/collections/getrecord/WAGMU_BA358> [accessed 19 December 2019].
} 
painting enamel—finely ground enamel powder mixed with oil of spike—was used as the printing black. The enamel pigment was worked into the engraved surface with a strip of rubber as a substitute for a piece of tightly bound flannel and excess ink wiped from the surface. The palm of the hand was used to remove remaining residue, as described by Brolliet. White tissue paper was applied to the inked surface as a transfer medium and a printing press with steel rollers and felt blankets was used to apply pressure to the transfer pigment from plate to tissue.

Two experiments with the printed tissue were undertaken: the first application was on a flat white enamel copper plaque; the second, on a white enamelled convex oval plaque of the same dimension as BA358. In both instances three coats of white wet-process enamel, fired at $800^{\circ} \mathrm{c}$ were applied.

In the first experiment the plate was inked and dry tissue placed on the surface before it was run through the printing press. The printed tissue was immediately removed from the copper plate and applied to the surface of the enamel. Transfer was possible but the application was problematic: the limited tack of the ink meant the paper was easily moved and the image smudged. However, it was surprising how easy it was to create a print. The paper was removed, the ink left to dry, and the plate was fired in an electric kiln at $800^{\circ} \mathrm{c}$ for approximately two minutes

In the second experiment the application of the printed transfer paper to the enamel surface was particular difficult. Three tests were undertaken. Firstly, printing on dry tissue then applying it directly on to the enamel, as per experiment one. However, the tissue had no flexibility and the small surface area of the paper combined with the 
limited amount of ink resulted in slippage smudging the print. Secondly, the tissue was soaked in water before printing. This made the paper more pliable and it stretched slightly thus making the transfer of the print more easy. However, to hold the tissue on to the oval enamel to prevent movement was difficult and it took skill to trap the printed tissue which was then lightly burnished from the centre out. The tissue occasionally lifted at the edges resulting in the image break up at the edge of the enamel similar to that on BA358. Thirdly, the tissue was moistened and excess water blotted off using a paper towel; it was then applied to the inked-up copper plate, pressed, then directly applied to the enamel. Then, as described by Brolliet, paper was placed over the tissue and by using the thumb, index and middle fingers, the paper was held down on three sides allowing the burnisher to be applied to the oval plaque trapped between the fingers. It thus became apparent that the paper may have been a means to prevent movement of the tissue on the enamel.

These investigations are still preliminary. The faintness of the replica print when compared to BA358 is, in part, probably due to the lack of depth to the engraved lines and consequently their ability to hold sufficient pigment to transfer to tissue and then enamel; this can be attributed to my lack of experience in engraving metal plates. In addition, the eighteenth-century printing media, perhaps contained a stronger staining agent. However the material tests go some way to beginning to understand the process and the complexities and struggles the craftsmen faced when applying prints to enamel.

\section{Conclusion}

Analysis of the printed surface through drawing on theoretical knowledge alone provides an incomplete picture. Similarly, the technical descriptions in primary 
literature leave many questions unanswered. The replication of an object creates material knowledge. The handling of substrates and the execution of processes allows for reflection on the technical descriptions in primary sources, and is a means to develop an understanding of the tacit knowledge of eighteenth-century Midlands craftsmen not made explicit in the written descriptions.

Analysing the imperfections found on printed enamels using a craftsmanship-framed lens helped clarify an ambiguous eighteenth-century technical explanation. Instructions around keeping the mordant moist and ensuring the paper remains static were tested through making in the workshop, the results of which make apparent tacit knowledge integral to production. Replication of the printing process extends that knowledge, making obvious key functions not readily apparent through text-based evidence. How the paper overlaid the print and enamel upon which the burnisher's pressure was applied, appears to have been a simple ad hoc gripping device. The experiments also help differentiate problems with the application of tissue prints to enamels. They highlighted that application on larger flat surfaces was a relatively simple process whilst on the small curved enamels it was more difficult and that tissue application to irregular surfaces were much harder to hold in place and control. Marks on mounted enamel boxes, tell us something about the craftsman's struggles with materials. The curious parallel lines in the print of EM48, were probably caused by texture in either the paper or cloth, their presence suggests different papers or clothes were used, and that an acceptance of slight imperfections existed in the trade.

Given the presence of imperfect prints on a finished object it seems odd that the manufacturer would go to the expense of fitting a hinged mount to connect lid and box. 
Two explanations are possible. Firstly, if these are finished boxes for the market place it perhaps reveals something about what was considered market-ready by manufacturers, what levels of quality control took place and what customers deemed acceptable.

Secondly, it perhaps provides evidence that counters Hackwood's suggestion that image break-up often required touching up afterwards. ${ }^{43}$ It is clear from the evidence that the craftsman did not seem to have been bothered by these imperfections. However, another explanation is that perhaps apprentices completed the imperfect items as practice pieces. However, if this was the case, it seems odd that in the cases of EM23 and EM47 both mounts are rather ornate and clearly items too expensive to practice with.

Material experiments highlighted crucial knowledge about the shelf-life of prints - the time by which they needed to be applied before they dried out and became useless. Clearly there was an imperative to print and apply immediately. This raises questions in relation to how the work of different engravers exists on one box. Did a single Midlands manufactory have plates from a number of engravers in their ownership?

The process of transfer printing meant the knowledge and skill to create accomplished engraved plates could only be found amongst a small group of individuals. Within that circle Hancock was a key player and his work appeared on numerous boxes. During his time at Worcester, contrary to the norm, he marked his prints, often disguised but sometimes more explicit. ${ }^{44}$ This is one of the ways in which certain prints have been definitively attributed to Hancock. It is apparent that Hancock recognised the value in his skill and, in an age when copyright did not exist, his surreptitious marking was a way to be acknowledged. Engravers often created engravings of famous prints or work

\footnotetext{
${ }^{43}$ F. W. Hackwood Wednesbury Workshops; or, some account of the industries of a Black Country town [...] (Wednesbury: The Woden Press, 1889) p. 16.

${ }^{44}$ C. Cook, The Life and Work of Robert Hancock (London: Chapman \& Hall, 1948), pp. 15-30, 60, 79.
} 
from pattern books such as The Ladies Amusement. ${ }^{45}$ Hancock realised the value in his engravings and desired to keep ownership of them, taking plates with him after departing Worcester Porcelain. ${ }^{46}$ The appearance of his prints on enamels and porcelain, by different manufacturers, sometimes concurrently, is interesting, especially when considered in the context of a short shelf-life of the printed tissue: was he selling copies of the engraved plates or the right to use them? If the latter how did this function? Did he print and apply at the works, or did he oversee others? Did he move around with the plates as a peripatetic engraver?

The box as a montage of prints is long established, prints being present that are clearly the work of different hands - for example the image of Henry Pelham inside the lid of box EM23. The print is clearly much less sophisticated than appears on the top, if these were both applied in the same manufactory why juxtapose if you had the engraving skills to produce equally sophisticated prints? Perhaps the Pelham print was applied later, but this would not be possible once lid and box were mounted. Furthermore, in some cases difference extended to the material quality - a glossy printed enamel top combined with a matt white enamel box. Established thought suggests that where print styles differ it is because the lids originated at Battersea and were bought by Midlands makers for use on their own boxes. However, it seems unlikely that this can be the explanation in all cases, given that short operating period for York House and the volume of production stock required by the Midlands workshops. The question then is whether these manufacturers were acquiring lids from elsewhere, perhaps to have the all

\footnotetext{
${ }^{45}$ R. Sayer, Ladies Amusement: Or, The Whole Art of Japanning Made Easy (London: Robert Sayer 1760)

${ }^{46}$ C. Cook, The Life and Work of Robert Hancock (London: Chapman \& Hall, 1948), pp. $69-70$.
} 
important celebrity print on the lid and then used their own engravers/printers to print and decorate the box side. However this is conjecture.

The perfection of printed enamel objects in the Wolverhampton Art Gallery collection shows that the trade's craftsmen had mastery of the transfer-print process. However, paradoxically, the museum objects with imperfections are the most useful in understanding undocumented making practices of the craftsmen who worked in this regionally significant trade. Whilst the different aesthetics of the perfectly printed decoration-suggestive in itself of possible variations and evolution in production process used — has been recognised as a means to assign objects to Midlands workshops, misprints provide a further means to delineate ware to different manufacturers if groupings and duplication of errors can be established across objects. Furthermore, it should be remembered that the process of applying and firing of transfers to enamels in the trade would have been different from that of ceramics, the scale of enamel ware sometimes being much smaller and the enamel and metal substrate thinner-requiring much shorter firing times and consequently easier to over-fire. Because of this, knowledge of transfer printing on enamel perhaps should not be assimilated from the literature describing similar activities in the ceramic trade. Consequently, the enamel print irregularities reveal important clues to how prints were applied; the sequence of applications, and the craftsmen's struggles with process particular to the trade. The faded prints on Midland-attributed ware highlight the printed tissue's shelf life and thus the importance of the proximity of the place of printing to that of decorating - illuminating workshop layout or juxtaposition with other trades. This brings into focus the logistics of how the printing plates in the ownership of celebrity engravers such as Hancock were used when they appeared on different Midlands 
manufacturers wares and how the diverse skills offered locally by allied trades — such as metal engravers to duplicate designs - were integral to supporting production.

Ultimately, transfer-printing was a significant technical advancement of the period, one that transformed ceramic production. Because its invention is credited to Birminghama place synonymous with metal trades - it should be remembered that transfer printing was utilised in, and would have evolved through, the manufacture of enamelled metalware of the town and the neighbouring district of South Staffordshire. I would suggest, it is in these workshops-where description of the making activities are scant in primary literature - that knowledge about the critical role the Midlands played in the development of transfer-printing can be found and therefore warrants further research. 


\section{Acknowledgments}

This research was only possible with the kind support of Wolverhampton Arts and Culture, the staff at Wolverhampton Art Gallery and collections officer Sophie Heath. Museum object photography was undertaken by the author, however, the copyright reproduction of images containing Wolverhampton collection enamels lies with Wolverhampton Arts and Culture. 